\title{
Development of Environment Friendly Paddy Ecosystem for Sustainable Rice Farming through Soil Amendments with Biochar and Alternate Wetting-Drying Irrigations
}

\author{
Muhammad Aslam Ali ${ }^{*}{ }^{(1)}$, Md. Rajib Hassan"1, Zubair Al Islam¹, Sanjit Chandra Barman1, \\ Badiuzzaman Khan'1, Rehana Khatun', Hafsa Jahan Hiya', Md. Touhidul Islam² \\ ${ }^{1}$ Department of Environmental Science, Bangladesh Agricultural University, Mymensingh, Bangladesh \\ ${ }^{2}$ Department of Irrigation and Water Management, Bangladesh Agricultural University, Mymensingh, Bangladesh \\ Email: *aslam.envs@bau.edu.bd, mdzubair13326@gmail.com, rajibhassanraju750@gmail.com, sanjit232@yahoo.com, \\ mbkhan@bau.edu.bd, rehana_envsc@bau.edu.bd, hafsa_envsc@bau.edu.bd, touhidul.iwm@bau.edu.bd
}

How to cite this paper: Ali, M. A., Hassan, Md. R., Al Islam, Z., Barman, S. C., Khan, B., Khatun, R., Hiya, H. J., \& Islam, Md. T. (2021). Development of Environment Friendly Paddy Ecosystem for Sustainable Rice Farming through Soil Amendments with Biochar and Alternate Wetting-Drying Irrigations. American Journal of Climate Change, 10, 581-596.

https://doi.org/10.4236/ajcc.2021.104029

Received: October 8, 2021

Accepted: December 28, 2021

Published: December 31, 2021

Copyright $\odot 2021$ by author(s) and Scientific Research Publishing Inc. This work is licensed under the Creative Commons Attribution-NonCommercial International License (CC BY-NC 4.0). http://creativecommons.org/licenses/by-nc/4.0/ (c) (i) (3) Open Access

\begin{abstract}
Climate change may badly affect the availability of water and soil nutrients to rice plant. Research experiments were conducted at the Environmental Science Departmental field, Bangladesh Agricultural University, Mymensingh during July 2017 to June 2019, to find out the suitable combination of biochar with inorganic fertilizers for minimizing seasonal yield scaled $\mathrm{CH}_{4}$ emissions, reducing global warming potentials (GWPs) and sustainable rice farming under feasible irrigation practices. There were ten experimental treatments with different combinations of inorganic NPKS fertilizers and biochar (15 - $30 \mathrm{t} / \mathrm{ha})$ under conventional flooding $(\mathrm{CF})$ and alternate wetting-drying irrigations (AWDI). This study revealed that NPKS fertilization (50\% of the recommended doze) with $15 \mathrm{t} /$ ha biochar amendments under AWD irrigation maximized rice yield $6750 \mathrm{~kg} / \mathrm{ha}$ and $4380 \mathrm{~kg} / \mathrm{ha}$ in dry boro and wet aman seasons respectively, while the lowest rice yield $1850 \mathrm{~kg} / \mathrm{ha}$ and $1550 \mathrm{~kg} / \mathrm{ha}$ were recorded in continuously irrigated control treatment $\left(\mathrm{T}_{1}\right)$ during the dry and wet seasons respectively. Seasonal cumulative $\mathrm{CH}_{4}$ emission, yield scaled $\mathrm{CH}_{4}$ emission and GWPs were suppressed significantly with biochar amendments 15 - $30 \mathrm{t} / \mathrm{ha}$ under both conventional and AWDI irrigation systems during the wet and dry seasons of rice cultivation. Significant interactions were observed among biochar amendments and irrigation practices during the dry boro rice cultivation. Dry seasonal cumulative $\mathrm{CH}_{4}$ emissions were decreased by $14.7 \%, 18.9 \%$ and $24.8 \%$ with biochar amendments at $15 \mathrm{t} / \mathrm{ha}, 20 \mathrm{t} / \mathrm{ha}$ and $30 \mathrm{t} / \mathrm{ha}$ respectively under conventional irrigation; while cumulative $\mathrm{CH}_{4}$ emissions were reduced by $10.6 \%, 26 \%$ and $41.6 \%$ respectively, under AWDI
\end{abstract}


system. Finally, total global warming potentials (GWPs) were decreased by $6 \%-15 \%, 13 \%-30 \%$ with biochar amendments under conventional and AWDI irrigations respectively, in wet season; while global warming potentials (GWPs) also decreased by $14 \%-25 \%, 11 \%-42 \%$ with biochar amendments under conventional and AWDI irrigations, respectively, in the dry boro season. Biochar amendments increased water productivity index to some extent, but AWD irrigations significantly increased water productivity over the conventional irrigation in both wet and dry seasons. After experimental period, it was found that soil porosity, redox status, soil organic carbon (SOC) as well as overall soil properties were improved significantly with biochar amendments and AWD irrigations. Conclusively, biochar amendments@15 - 20 $\mathrm{t} /$ ha with half of the recommended inorganic (NPKS) fertilizers under alternate wetting-drying irrigations revealed an environment friendly integrated package approach to reduce seasonal cumulative $\mathrm{CH}_{4}$ emissions as well as GWPs, while improving rice rhizosphere environment and rice productivity to meet the national food security.

\section{Keywords}

$\mathrm{CH}_{4}$ Flux, GWPs, AWDI, Yield Scaled $\mathrm{CH}_{4}$ Emission, Dry Boro Rice, Rainfed Aman Rice

\section{Introduction}

Rice is the staple food grain crop for the people of Bangladesh, which provides about $370 \mathrm{kcal}$ energy from $100 \mathrm{~g}$ grains. In this country about $84 \%$ cropped area is used for rice cultivation, with total annual production 33.89 million metric tons (BBS, 2015). Bangladesh has a monsoon climate as well as hot humid subtropical climate with a four-month wet season and an eight-month dry season (Ahmad et al., 2014). The main rice growing seasons in Bangladesh are known as aman or wet season, aus or spring season and boro or dry season which is fully irrigated. Irrigated dry season boro rice is the main crop which is the highest yielding of the three rice seasons (Ahmed et al., 2013). BBS (2015) gives the average yield figures for boro rice as 3.86 tonnes/ha when sown with high-yielding conventional varieties, and an average of 4.75 tonnes/ha when sown with hybrid varieties. The average yield of rice in Bangladesh is about $3.0 \mathrm{t} \mathrm{ha}^{-1}$, which is very low (BBS, 2015). Irrigation water supply is the prime requirement for sustainable rice farming, especially in the dry boro season, however, water scarcity is a vital problem for dry boro season rice production. In Bangladesh, irrigated boro rice (dry period) cultivation mainly contributes (about 55\%) to total rice production (about 33.89 million tons) in the country. Unfortunately, irrigation water is a costly input to rice farming, which accounts for $28 \%$ of the total cost of rice production. It has been estimated that approximately 22 million hectares of irrigated dry-season rice may suffer from "economic water scarcity" in Asia by 2025 (Tuong, 2003). Furthermore, rice farming may become increasingly threatened due 
to climate change and extreme natural disasters in terms of increasing temperatures and uncertainty of precipitation, drought, floods and salinity (IPCC, 2007).

Irrigated rice farming is an integral part of rice production system in Bangladesh, which contributes greatly towards total annual rice production and food security. However, our rice cultivation especially in dry rabi season requires large amount of irrigation water, which is of great environmental concern due to energy crisis and methane $\left(\mathrm{CH}_{4}\right)$ emission from rice field to the atmosphere, which acts as a potential greenhouse gas with 25 times global warming potential than carbon dioxide (Nieder \& Benbi, 2008). Boro rice cultivation is mostly dependent on irrigation water supply and the aman rice cultivation is partly irrigation water dependent. As groundwater is the main source of irrigation in Boro rice field in northwestern Bangladesh, higher abstraction rate of groundwater may cause negative impacts on groundwater resources in the region. The declining groundwater level may cause an increase in irrigation cost in the area and the economic losses of farmers. It has already been predicted that Bangladesh is going to face severe water crisis during dry season within the next couple of years. In this regard, alternate wetting and drying (AWD) of paddy field, developed by International Rice Research Institute, could save a significant volume of irrigation water $15 \%$ $30 \%$ (Bouman et al., 2007) for rice production, mitigate $\mathrm{CH}_{4}$ emission and sustain rice productivity.

The fertility of crop field in Bangladesh has been declining day by day due to continuous cropping and mining of nutrients, and indiscriminate use of chemical fertilizers. In this regard, biochar, mainly the carbon enriched materials with minute amount of plant nutrients obtained from organic matter under high pyrolysis temperature and oxygen limited condition (Lehmann \& Rondon, 2006), could be the best organic manures to rejuvenate degraded soils. Biochar is an anaerobic pyrolysis product derived from organic material, resistant to easy degradation and capable of restoring soil carbon for a longer period of time by reducing greenhouse emission from soil to the atmosphere. Moreover, the use of biochar will cut down the amount of chemical fertilizers for rice cultivation and GHGs emissions may be suppressed by modifying the paddy ecosystem. It has already reported that combined application of rice husk biochar and FYM with reduced chemical fertilizer under less water inputs was found effective to sustain wheat crop yield in the highly vulnerable dry tropical agro-ecosystem of India (Singh et al., 2019). Furthermore, Singh et al. (2021) reported that compatible agricultural practices based on specific agroecosystem could be effective for climate change adaptations. Therefore, this study was undertaken to determine the suitable combination of biochar and chemical fertilizer (NPKS) for sustaining rice productivity, minimizing yield scaled methane emissions and improving paddy ecosystem through water savings AWDI system.

\section{Materials and Methods}

\subsection{Experimental Location and Meteorological Condition}

The present research work was conducted at Bangladesh Agricultural University 
Field, Mymensingh during wet season, Aman rice (July to November 2017 \& July to November 2018) and dry season boro rice cultivation (December 2017-May 2018; December 2018-May 2019). The experimental field was located at $24^{\circ} 0^{\prime} \mathrm{N}$ latitude and $90^{\circ} 25^{\prime} \mathrm{E}$ longitude at an elevation of $19 \mathrm{~m}$ above the sea level which falls under Agro-ecological region of the Old Brahmaputra Alluvial Tract (AEZ 9). The experimental field was medium high land with moderate drained condition. The soil was silty loam in texture (Sand: $23.5 \%$, Silt: $73 \%$, Clay: $3.5 \%$ ) having a soil $\mathrm{pH}$ value 5.9 , organic $\mathrm{C} 1.0 \%$, total $\mathrm{N} 0.09 \%$, available phosphorus (P) $11.5 \mathrm{ppm}$, available Sulphur (S) $11.0 \mathrm{ppm}$ and exchangeable potassium (K) $0.09 \mathrm{ppm}$. The experimental area was under the sub-tropical climate that is characterized by high temperature, high humidity and heavy rainfall with occasional gusty winds in wet kharif season (April to September) and less rainfall associated with moderately low temperature during the dry rabi season (October to March).

\subsection{Experimental Design, Treatments, Field Preparation and Rice Cultivation}

The experiment was laid out in a randomized complete block design (RCBD) with ten treatments and three replications. The total numbers of plots were 30 . Each plot size was $6 \mathrm{~m} \times 5 \mathrm{~m}=30 \mathrm{~m}^{2}$. The experimental treatments are $\mathrm{T}_{1}$ No NPKS, no amendments with conventional irrigation (CI); $\mathrm{T}_{2}$ Farmers practice (100\% recommended NPKS with CI; $\mathrm{T}_{3}$ NPKS) $50 \%$ of the recommended NPKS with Biochar (@15 t/ha) under CI; $\mathrm{T}_{4}$ NPKS 25\% of the recommended dozeof NPKS with biochar (@20 t/ha) under CI; T No NPKS with biochar (@30 t/ha) under CI; $\mathrm{T}_{6}$ No NPKS, no amendments with AWDI irrigation; $\mathrm{T}_{7}$ Farmers practice (100\% recommended NPKS) with AWDI; $\mathrm{T}_{8}$ NPKS (50\% of the recommended dozeof NPKS with biochar@15 t/ha) under AWDI; T 9 NPKS 25\% of the recommended dozeof NPKS with biochar@20 t/ha under AWDI; $T_{10}$ No NPKS with Biochar (@30 t/ha) under AWDI. Rice cultivars BINA dhan-17and BINA dhan-10 were cultivated in wet aman and dry boro seasons, respectively.

\subsection{Fertilizer Application}

The fertilizer treatments were used in this experiment based on BARC fertilizer recommendation guide, 2012. Biochar as soil amendment was used in this experiment with NPKS. Standard doses of fertilizer were applied to the experimental field as recommended by Bangladesh Institute of Nuclear Agriculture (BINA) for BINA dhan-17. The whole amount of Urea, Triple Super Phosphate (TSP), Muriate of potash (MoP), Gypsum and Zinc Sulphate were applied for both Conventional flooding and AWDI practices. Urea was applied at final preparation, 40 - 45 days after transplant (DAT), 60 - 65 DAT, 75 - 85 DAT. The dose of fertilizer applied were urea $120 \mathrm{~kg} / \mathrm{ha}$, TSP $80 \mathrm{~kg} / \mathrm{ha}$, Muriate of potash $50 \mathrm{~kg} / \mathrm{ha}$, gypsum $30 \mathrm{~kg} / \mathrm{ha}$, Zinc Sulphate $1.5 \mathrm{~kg} / \mathrm{ha}$. The composition of the applied rice husk biochar were organic $\mathrm{C} 36 \%$, total $\mathrm{N} 1.2 \%, \mathrm{P}_{2} \mathrm{O}_{5} 1.1 \%, \mathrm{~K}_{2} \mathrm{O} 1.2 \%, \mathrm{SiO}_{2} 1.0$ 
ppm, $\mathrm{SO}_{3} 1.6 \mathrm{ppm}, \mathrm{MnO} 0.9$ ppm, C/N ratio 30:1, pH 8.9.

\subsection{Gas Sampling and Analysis}

Gas samples were collected by the modified closed-chamber method (Rolston, 1986; Ali, 2008) during the rice cultivation. The dimension of each chamber was $(120 \mathrm{~cm} \times 60 \mathrm{~cm} \times 60 \mathrm{~cm})$. Gas samples were collected once a week after rice transplanting. Gas samples were collected by a $50 \mathrm{ml}$ air-tight syringe at 0,15 and 30 minutes intervals after chamber placement over the rice plants. The samples were analyzed to determine the concentration of $\mathrm{CH}_{4}$ gas by Gas Chromatograph (Shimadzu/GC 2014, Japan) equipped with a Flame Ionization Detector (FID). The analysis column used a stainless steel column packed with Porapak NQ (Q 80 - 100 mess). The temperatures of column, injector and detector were adjusted at $100^{\circ} \mathrm{C}, 200^{\circ} \mathrm{C}$, and $200^{\circ} \mathrm{C}$ respectively.

\subsection{Calculation of $\mathrm{CH}_{4}$ Flux}

$\mathrm{CH}_{4}$ Flux $\left(\mathrm{F}=\mathrm{mg} \cdot \mathrm{m}^{-2} \cdot \mathrm{hr}^{-1}\right)$ was calculated using the following formula (Rolston, 1986)

$$
F=\rho \cdot V / A \times \Delta C / \Delta t \times 273 / T
$$

where, $\rho=$ gas density $\left(\mathrm{CH}_{4}=0.714\right) ; V=$ volume of chamber $\left(\mathrm{m}^{3}\right) ; A=$ area surface of the chamber (m); $\Delta C l=$ average rate of increase of $\mathrm{CH}_{4}$ gas concentration in the chamber; $\Delta t=$ time and $T=273+$ mean temperature within the chamber $\left({ }^{\circ} \mathrm{C}\right)$ [Conversion factor from ${ }^{\circ} \mathrm{K}$ to ${ }^{\circ} \mathrm{C}$ ].

Total methane flux for the entire cropping period was computed by the formula (Singh et al., 1999): total $\mathrm{CH}_{4}$ flux $=\sum_{i=1}^{n}(\mathrm{Ri} \times \mathrm{Di})$, where, $R i=$ rate of methane flux $\left(\mathrm{g} \cdot \mathrm{m}^{-2} \cdot \mathrm{d}^{-1}\right)$ in the ith sampling interval, and $n=$ number of sampling intervals.

\subsection{Estimation Global Warming Potential (GWP) of $\mathrm{CH}_{4}$}

To estimate the GWP, $\mathrm{CO}_{2}$ is typically taken as the reference gas, and an increase or reduction in emission of $\mathrm{CH}_{4}$ is converted into " $\mathrm{CO}_{2}$-equivalents" by means of their GWPs. In this study, we used the IPCC factors to calculate the combined GWP for 100 years $\left(\mathrm{GWP}=25 \times \mathrm{CH}_{4}, \mathrm{~kg} \mathrm{CO}_{2}\right.$-equivalents ha ${ }^{-1}$ ) from $\mathrm{CH}_{4}$ under various agricultural irrigation practices. In addition, the greenhouse gas intensity (GHGI) was calculated by dividing GWP by grain yield for rice (Mosier et al., 2006).

\subsection{Determination of Water Savings}

Water discharge from the irrigation pipe was calculated as the volume of water $\left(\mathrm{m}^{3}\right)$ flowing through the pipe and measured as cubic meter per second $\left(\mathrm{m}^{3} / \mathrm{s}\right)$. The time required to maintaining appropriate water levels in the main plots during each irrigation was noted and summed to calculate the total volume of water applied to the plots throughout the cropping season. Water saving per- 
centage was calculated using the formula:

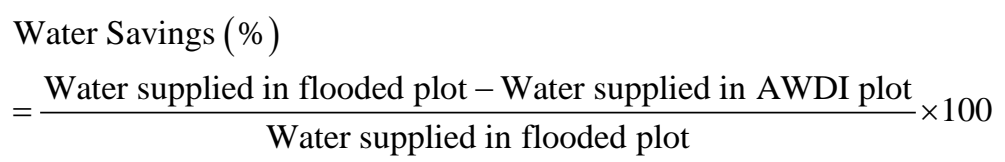

\subsection{Estimation of Water Productivity Index}

Water productivity index is the ratio of crop yield $(\mathrm{kg} / \mathrm{ha})$ per unit water $\left(\mathrm{m}^{3} / \mathrm{ha}\right)$ supplied (Jaafar et al., 2000) and calculated as follows:

$$
\text { Water productivity index }\left(\mathrm{kg} / \mathrm{m}^{3}\right)=\frac{\text { Grain Yield }\left(\frac{\mathrm{kg}}{\mathrm{ha}}\right)}{\text { Total water supplied }\left(\frac{\mathrm{m}^{3}}{\mathrm{ha}}\right)}
$$

\subsection{Soil Properties}

Soil redox potential (Eh) were measured during rice cultivation at certain time intervals by glass electrode Eh meter. At harvesting stage, soil bulk density (BD) was analyzed using cores (volume $100 \mathrm{~cm}^{3}$, inner diameter $5 \mathrm{~cm}$ ), filled with fresh moisture soils. The collected core samples were oven dried at $105^{\circ} \mathrm{C}$ for 24 $\mathrm{h}$ and then measured the weight of dried core samples. Soil porosity was calculated using $\mathrm{BD}$ and particle density $\left(\mathrm{PD}, 2.89 \mathrm{Mg} \cdot \mathrm{m}^{-3}\right.$ ) according to the equation: porosity $(\%)=(1-\mathrm{BD} / \mathrm{PD}) \times 100$. At harvesting stage, chemical properties of the collected soil samples were analyzed for organic carbon by wet oxidation method, total nitrogen by Micro-kjeldhal method (Nelson \& Sommers, 1980), available phosphorus by Colorimetric method (Olsen \& Sommers, 1982), available $S$ (by the calcium chloride $0.15 \%$ extraction method), available Si (1M $\mathrm{Na}$-acetate, $\mathrm{pH}$ 4.0, UV Spectrometer) were determined following standard methods. Exchangeable calcium $(\mathrm{Ca})$, sodium $(\mathrm{Na})$ and potassium $(\mathrm{K})$ were extracted from soil using $1 \mathrm{M} \mathrm{CH}_{3} \mathrm{COONH}_{4}$ solution and their concentrations in the extract were directly determined by Flame photometer (Model: FP 902 PG Instrument). Total iron and free iron oxides in soil were extracted by Diethylene Tri-amine Penta Acetate (DTPA) solution and its concentration in the extract was determined directly by an Atomic Absorption Spectrophotometer (Loeppert \& Inskeep, 1996). The concentrations of total dissolved iron and ferrous iron in the leached water samples were determined by 1,10-phenanthroline method.

\subsection{Statistical Analysis}

The compiled and tabulated data of rice growth, yield, soil properties and $\mathrm{CH}_{4}$ emission were statistically analyzed by Analysis of Variance (ANOVA) to examine whether treatment effects were significant or not. The mean differences among treatments were compared by Duncan's Multiple Range Test. The computer software MSTAT-C was used for statistical analysis. 


\section{Results}

\subsection{Trends of $\mathrm{CH}_{4}$ Emission Rate and Soil Redox Potential during Rice Cultivation}

$\mathrm{CH}_{4}$ emission rates and soil redox potentials were significantly affected by biochar amendments and irrigation practices during the dry boro season and wet Aman season (Figure 1 \& Figure 2). In the dry boro season, $\mathrm{CH}_{4}$ emission rate was very low within 7 - 14 DAT which increased gradually with plant development stages and peak $\mathrm{CH}_{4}$ flux (approximately $40 \mathrm{mg} \mathrm{CH}_{4} \mathrm{~m}^{-2} \mathrm{~h}^{-1}$ ) was recorded in T2 treated (100\% recommended NPKS under conventional irrigation) rice planted plot around 63 - 70 DAT (Figure 1).
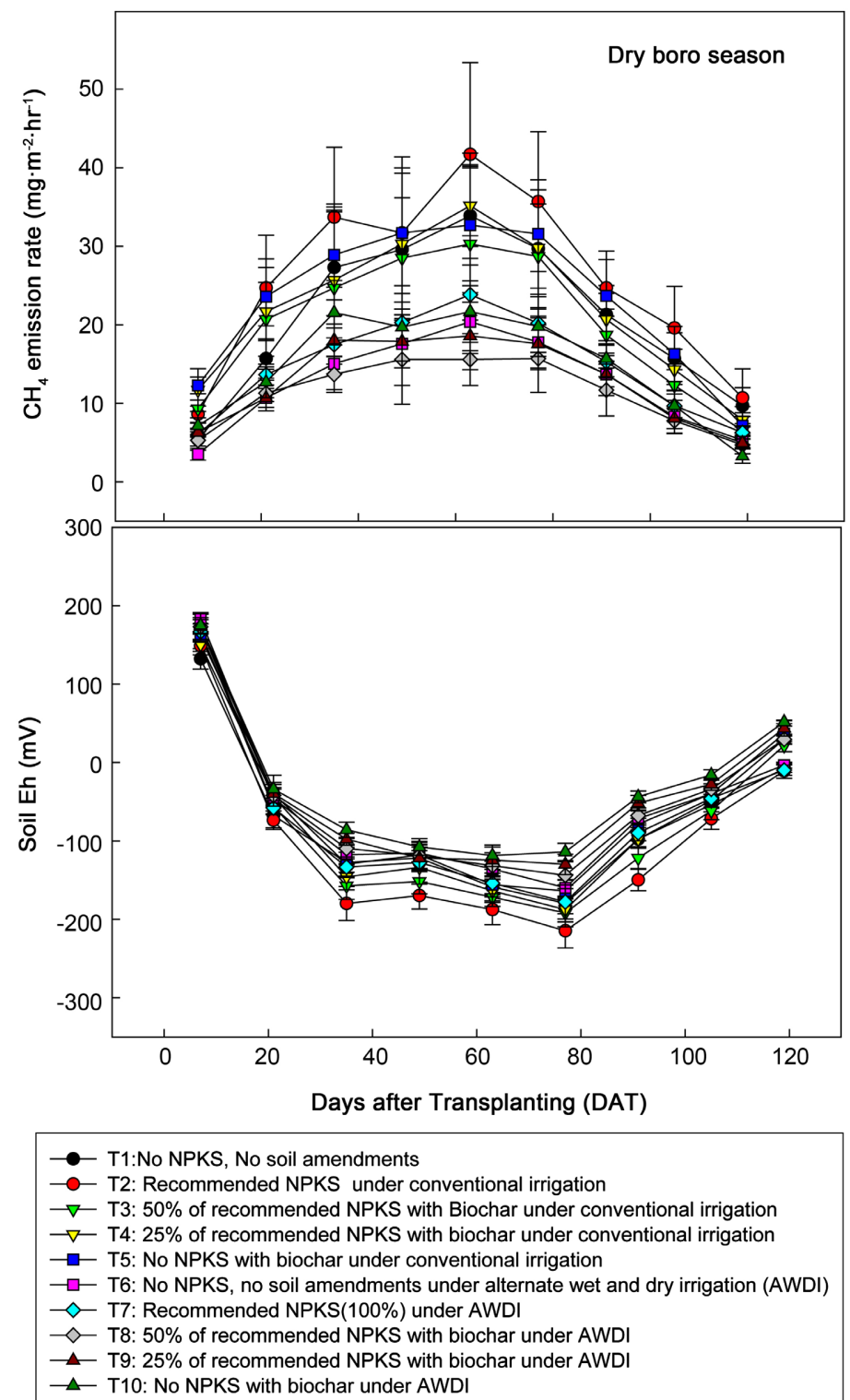

Figure 1. Trends of $\mathrm{CH}_{4}$ fluxes and soil redox potentials during dry boro season rice cultivation (note: error bars indicate standard deviation among the mean values). 

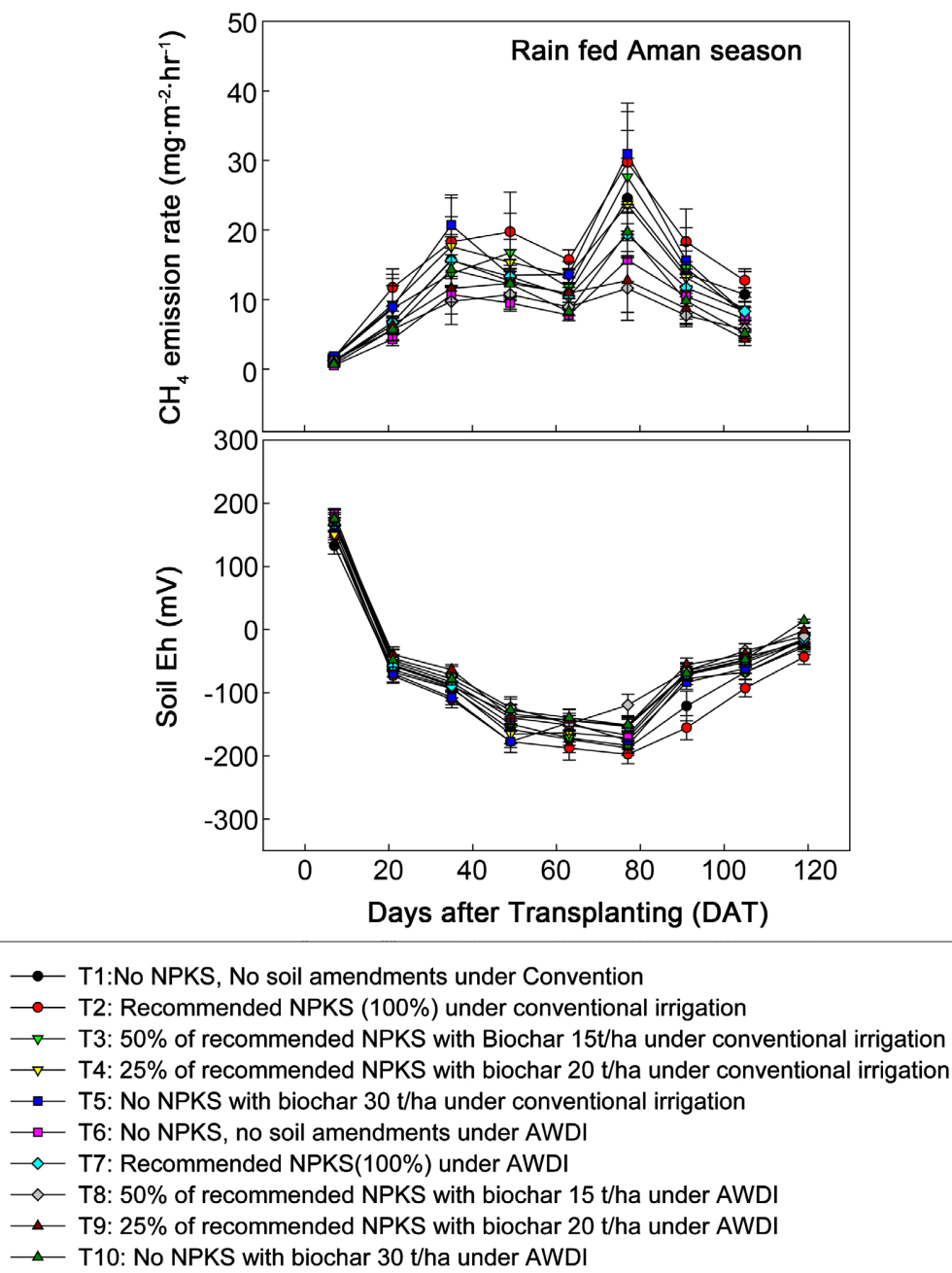

Figure 2. Trends of $\mathrm{CH}_{4}$ fluxes and soil redox potentials (Eh) during wet Aman season rice cultivation (note: error bars indicate standard deviation among the mean values).

On the other hand, soil redox potential value started to decrease after rice transplanting and irrigation water application. Intense soil reduction condition (Eh value $-200 \mathrm{mV}$ to $-250 \mathrm{mV}$ ) was developed under the conventional irrigation method within 70 - 77 DAT, which contributed significant amount of $\mathrm{CH}_{4}$ emissions from rice field to the atmosphere (Figure 1). However, AWDI irrigation method showed less $\mathrm{CH}_{4}$ emissions compared to conventional irrigation method. Biochar amended (20 - $30 \mathrm{t} / \mathrm{ha}$ ) rice planted plots emitted lower $\mathrm{CH}_{4}$ from conventional and AWDI practices, although biochar under AWDI mostly improved soil redox status and showed least amount of $\mathrm{CH}_{4}$ emissions. During the rainfed aman rice cultivation $\mathrm{CH}_{4}$ emission rate was very low within the 21 DAT which increased gradually with plant development stages and peaked $\left(\mathrm{CH}_{4}\right.$ flux $30 \mathrm{mg} \mathrm{CH}_{4} \mathrm{~m}^{-2} \mathrm{~h}^{-1}$ ) in T2 treated (100\% recommended NPKS under conventional irrigation) rice planted plot at $77 \mathrm{DAT}$ (Figure 2), thereafter decreased sharply towards rice harvesting stage. 
Soil redox potential value also found highly negative (Eh value $-180 \mathrm{mV}$ to $-220 \mathrm{mV}$ ) i.e. most reduction condition was observed around $77 \mathrm{DAT}$, which could be a vital factor for significant $\mathrm{CH}_{4}$ emissions from rice rhizosphere to the atmosphere (Figure 2). Among the treatments, T2 treated rice planted plot showed maximum reductive condition under conventional irrigation, biochar amendments at $20-30 \mathrm{t} / \mathrm{ha}$ under AWDI improved soil redox status, which eventually lowered $\mathrm{CH}_{4}$ emissions.

\subsection{Cumulative $\mathrm{CH}_{4}$ Flux, GWPs and Yield Scaled $\mathrm{CH}_{4}$ Emissions (GHGI) under Biochar Amendments and AWDI}

Cumulative $\mathrm{CH}_{4}$ flux varied among the treatments, which may be due to biochar amendments and irrigation practices as well as seasonal effects. In the wet season, highest cumulative $\mathrm{CH}_{4}$ flux $(183.5 \mathrm{~kg} / \mathrm{ha} /$ season) was observed in $\mathrm{T} 2(100 \%$ recommended NPKS without biochar) under conventional irrigation, while the lowest cumulative $\mathrm{CH}_{4}$ flux ( $97.9 \mathrm{~kg} / \mathrm{ha} /$ season) was recorded in T10 (biochar 30 t/ha) under AWDI irrigation (Table 1).

The maximum cumulative $\mathrm{CH}_{4}$ flux $(217 \mathrm{~kg} / \mathrm{ha} /$ season $)$ was found in $\mathrm{T} 2(100 \%$ recommended NPKS) under CI, while lowest cumulative $\mathrm{CH}_{4}$ flux $(98.6 \mathrm{~kg} / \mathrm{ha} / \mathrm{sea}$ son) was recorded in T10 (biochar $30 \mathrm{t} / \mathrm{ha}$ ) under AWDI irrigation in the dry boro season (Table 1). Biochar amendments significantly decreased seasonal cumulative $\mathrm{CH}_{4}$ emissions, GWPs and yield scaled $\mathrm{CH}_{4}$ emissions (Table 1). In the wet season, biochar amendments $30 \mathrm{t} / \mathrm{ha}$ in T5 and T10 treated field plots showed the least amount of total cumulative $\mathrm{CH}_{4}$ emissions, GWPs and yield scaled $\mathrm{CH}_{4}$ emissions from rice field under the conventional and AWDI systems. It is interesting to mention that AWDI treated rice planted plots showed significantly lower amount of cumulative $\mathrm{CH}_{4}$ emissions, GWPs and yield scaled $\mathrm{CH}_{4}$ emissions compared to the conventional irrigated rice fields.

Rice cultivation during the dry boro season resulted significantly higher amount of total cumulative $\mathrm{CH}_{4}$ emissions, GWPs and yield scaled $\mathrm{CH}_{4}$ emissions compared to those parameters in wet Aman season (Table 1). Highest seasonal cumulative $\mathrm{CH}_{4}$ emission (217 kg/ha/season) and GWPs (5425 $\mathrm{kg} \mathrm{CO}$ eq.ha ${ }^{-1}$ ) were recorded from the NPKS (100\%) fertilized plot (T2) under conventional irrigation, while the lowest seasonal cumulative $\mathrm{CH}_{4}$ emission $(98.6 \mathrm{~kg} / \mathrm{ha} / \mathrm{season})$ and GWPs (2465 $\mathrm{kg} \mathrm{CO}_{2}$ eq.ha ${ }^{-1}$ ) were found in T10 treated (biochar 30/ha) plot under AWDI irrigation system. Yield scaled $\mathrm{CH}_{4}$ emissions (GHGI) were also recorded lowest in T9 (biochar $20 \mathrm{t} / \mathrm{ha}$ ) and T10 (biochar 30/ha) treated plots under both conventional and AWDI systems (Table 1).

\subsection{Post-Harvest Soil Properties}

Biochar amendments increased soil porosity, SOC and $\mathrm{T}-\mathrm{N}$, soil $\mathrm{pH}$, available phosphate, available Sulphur (S), exchangeable $\mathrm{K}^{+}$and free iron oxides in the post-harvest soils (Table 2).

Soil redox status also improved in the biochar amended field plots, probably due to the cumulative effects of free iron oxides $\left(\mathrm{Fe}_{2} \mathrm{O}_{3}\right)$ in the rice rhizosphere 
Table 1. Rice yield, water productivity, GWP and yield scaled $\mathrm{CH}_{4}$ emission under different combinations of biochar and NPKS fertilizers in conventional and AWDI irrigation practices.

\begin{tabular}{|c|c|c|c|c|c|c|c|c|}
\hline $\begin{array}{l}\text { Rice } \\
\text { growing } \\
\text { seasons } \\
\text { (A) }\end{array}$ & $\begin{array}{l}\text { Treatments (B) } \\
\text { Biochar } \\
\text { amendments } \\
\text { and irrigation } \\
\text { practices }\end{array}$ & $\begin{array}{l}\text { Grain } \\
\text { yield } \\
(\mathrm{kg} / \mathrm{ha})\end{array}$ & $\begin{array}{l}\text { Harvest } \\
\text { Index } \\
(\%)\end{array}$ & $\begin{array}{c}\text { Water } \\
\text { productivity } \\
\mathrm{kg} \text { yield } / \mathrm{m}^{3} \\
\text { water }\end{array}$ & $\begin{array}{c}\text { Water } \\
\text { required } \\
\left(\mathrm{L}^{-1} \mathrm{~kg} \text { rice }\right. \\
\text { production }\end{array}$ & $\begin{array}{c}\text { Cumulative } \\
\mathrm{CH}_{4} \text { flux } \\
\text { (kg/ha/season) }\end{array}$ & $\begin{array}{c}\mathrm{GWP}\left(\mathrm{kg} \mathrm{CO} \mathrm{CO}_{2}\right. \\
\left.\mathrm{eq} \cdot \mathrm{ha}^{-1}\right)\end{array}$ & 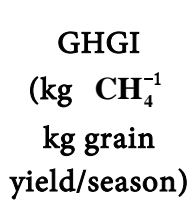 \\
\hline \multirow{10}{*}{ 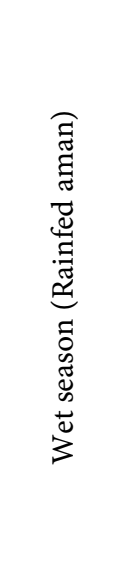 } & T1: F0CI & $1550 \mathrm{~h}$ & $30.9 \mathrm{f}$ & 0.184 & $5400 \mathrm{~b}$ & $169.6 \mathrm{bc}$ & $4240 \mathrm{bc}$ & $0.109 a$ \\
\hline & T2: F1CI & $4050 \mathrm{f}$ & $41.7 \mathrm{de}$ & 0.204 & $4900 c$ & $183.5 \mathrm{~b}$ & $4587 \mathrm{ab}$ & $0.045 \mathrm{c}$ \\
\hline & T3: F2CI & $4200 \mathrm{ef}$ & $42.5 \mathrm{~cd}$ & 0.214 & $4600 \mathrm{~cd}$ & $171.6 \mathrm{bc}$ & $4290 \mathrm{bc}$ & $0.040 \mathrm{c}$ \\
\hline & T4: F3CI & $4000 \mathrm{ef}$ & $39.7 \mathrm{de}$ & 0.221 & $4500 d$ & $163.5 \mathrm{c}$ & $4087 \mathrm{bc}$ & $0.041 \mathrm{c}$ \\
\hline & T5: F4CI & $3850 \mathrm{f}$ & $38.5 \mathrm{e}$ & 0.228 & $4300 \mathrm{~cd}$ & $155.6 \mathrm{~cd}$ & $3890 c$ & $0.04 c$ \\
\hline & T6: F0AWDI & $1750 \mathrm{gh}$ & $31.8 \mathrm{ef}$ & 0.254 & 3900de & $129.5 \mathrm{e}$ & $3237 d$ & $0.074 \mathrm{~b}$ \\
\hline & T7: F1AWDI & $4100 \mathrm{ef}$ & $41,6 \mathrm{~d}$ & 0.373 & $2700 \mathrm{f}$ & 135.6de & $3497 \mathrm{~cd}$ & $0.033 \mathrm{~d}$ \\
\hline & T8: F2AWDI & $4380 \mathrm{e}$ & $43.5 \mathrm{~cd}$ & 0.415 & $2400 \mathrm{fg}$ & $121.7 \mathrm{ef}$ & $3042 \mathrm{e}$ & $0.027 \mathrm{e}$ \\
\hline & T9: F3AWDI & $4250 \mathrm{ef}$ & $41.2 \mathrm{de}$ & 0.427 & $2300 \mathrm{~g}$ & $115.5 \mathrm{f}$ & $2656 f$ & $0.027 \mathrm{e}$ \\
\hline & T10: F4AWDI & $4160 \mathrm{ef}$ & $40.3 \mathrm{~d}$ & 0.435 & $2200 \mathrm{~g}$ & $97.9 \mathrm{~g}$ & $2447 \mathrm{~g}$ & $0.023 \mathrm{e}$ \\
\hline \multirow{10}{*}{ 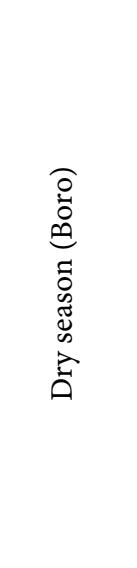 } & T1: F0CI & $1850 \mathrm{gh}$ & $30.5 f$ & 0.165 & $6000 a$ & $177 \mathrm{bc}$ & $4425 \mathrm{~b}$ & $0.095 \mathrm{ab}$ \\
\hline & T2: F1CI & $5500 d$ & $47.2 \mathrm{ab}$ & 0.205 & $4900 c$ & $217 \mathrm{a}$ & $5425 a$ & $0.039 \mathrm{~d}$ \\
\hline & T3: F2CI & $6580 \mathrm{ab}$ & $48.3 \mathrm{a}$ & 0.227 & $4600 \mathrm{~cd}$ & $185 \mathrm{ab}$ & $4625 \mathrm{ab}$ & $0.028 \mathrm{e}$ \\
\hline & T4: F3CI & $6250 \mathrm{bc}$ & $46.6 \mathrm{~b}$ & 0.239 & $4400 \mathrm{de}$ & $176 \mathrm{bc}$ & $4400 \mathrm{~b}$ & $0.028 \mathrm{e}$ \\
\hline & T5: F4CI & $5860 \mathrm{~cd}$ & $44.2 \mathrm{c}$ & 0.223 & $4500 \mathrm{~d}$ & $163 c$ & $4075 b c$ & $0.027 \mathrm{e}$ \\
\hline & T6: F0AWDI & $2180 \mathrm{~g}$ & $32.6 \mathrm{ef}$ & 0.264 & $3800 \mathrm{e}$ & $155 \mathrm{~cd}$ & $3875 c$ & $0.071 b$ \\
\hline & T7: F1AWDI & $5670 \mathrm{~cd}$ & $44.7 \mathrm{c}$ & 0.436 & $2300 \mathrm{~g}$ & $169 b c$ & $4225 b c$ & $0.029 \mathrm{e}$ \\
\hline & T8: F2AWDI & $6750 \mathrm{a}$ & $48.5 \mathrm{a}$ & 0.523 & $2000 \mathrm{~h}$ & $151 \mathrm{~d}$ & $3750 c$ & $0.023 \mathrm{e}$ \\
\hline & T9: F3AWDI & $6480 \mathrm{~b}$ & $46.9 \mathrm{~b}$ & 0.520 & 1900hi & $125 \mathrm{ef}$ & $3125 \mathrm{de}$ & $0.019 \mathrm{e}$ \\
\hline & T10: F4AWDI & $6050 c$ & $44.5 c$ & 0.530 & $1800 \mathrm{i}$ & $98.6 \mathrm{~g}$ & $2465 \mathrm{~g}$ & $0.016 \mathrm{f}$ \\
\hline \multirow{3}{*}{ ANOVA } & A & $* * *$ & $* *$ & ** & $* *$ & $* * *$ & ** & ** \\
\hline & B & $* * *$ & $* * *$ & $* * *$ & $* * *$ & $* * *$ & $* * *$ & $* * *$ \\
\hline & $\mathrm{A} \times \mathrm{B}$ & $* * *$ & ** & ** & ** & $* *$ & ** & $* *$ \\
\hline
\end{tabular}

Note. $\mathrm{T}_{1}$ : F0W1 (5 cm standing water No NPK) with level; $\mathrm{T}_{2}$ : F1W1 (NPKS 100\%) with $5 \mathrm{~cm}$ standing water level; $\mathrm{T}_{3}$ : F2W1 (NPKS $50 \%+15 \mathrm{t}$ biochar/ha with $5 \mathrm{~cm}$ standing water level; $\mathrm{T}_{4}: \mathrm{F} 3 \mathrm{~W} 1: \mathrm{NPKS}(25 \%)+20 \mathrm{t} / \mathrm{ha}$ biochar/ha with $5 \mathrm{~cm}$ standing water level; $\mathrm{T}_{5}: \mathrm{F}_{4} \mathrm{~W} 1$ : No NPKS (0) $+25 \mathrm{t}$ biochar/ha with $5 \mathrm{~cm}$ standing water level; $\mathrm{T}_{6}:$ F0W2: (No NPK) with AWDI irrigation; T7: F1W2: (NPKS (100\%) + 5 t biochar/ha with AWDI; T8: F2W2: NPKS (50\%) + 15 t biochar/ha with AWDI; T9: F3W2: NPKS $(25 \%)+20$ t biochar/ha with AWDI; T10: $\mathrm{F}_{4} \mathrm{~W} 2$ : No NPKS $(0)+25 \mathrm{t}$ biochar/ha with AWDI.

which enhanced electron activity in soil and acted as electron acceptor, thereby enhanced soil porosity (Table 2). At the end of the experiment maximum increment in soil porosity, soil $\mathrm{pH}, \mathrm{SOC}, \mathrm{SO}_{4}$-S and free iron oxides were found in biochar amended (20 - $30 \mathrm{t} / \mathrm{ha}$ ) field plots under conventional and AWDI systems. This may be due to the mineralization of organic $S$ from fertilizers and biochar. In addition, higher concentrations of free iron oxides in soil could be 
Table 2. Effect of biochar amendments and AWDI irrigation practices on chemical properties of post-harvest soil (after two years of cropping).

\begin{tabular}{|c|c|c|c|c|c|c|c|c|c|}
\hline Treatments & $\begin{array}{c}\text { Soil } \\
\text { porosity } \\
(\%)\end{array}$ & $\mathrm{pH}$ & $\begin{array}{c}\text { Soil } \\
\text { Organic } \\
\text { Carbon } \\
(\mathrm{g} / \mathrm{kg})\end{array}$ & $\begin{array}{c}\text { Total } \\
\text { Nitrogen } \\
(\%)\end{array}$ & $\begin{array}{c}\text { Available } \\
\text { P (ppm) }\end{array}$ & $\begin{array}{l}\text { Available } \\
\text { S (ppm) }\end{array}$ & $\begin{array}{c}\text { Ex. K } \\
\text { Potassium } \\
\text { (meq/100g) }\end{array}$ & $\begin{array}{l}\text { Soil Eh } \\
(\mathrm{mV})\end{array}$ & $\begin{array}{c}\text { Free iron } \\
\text { oxide } \\
(\mathrm{g} / \mathrm{kg})\end{array}$ \\
\hline Initial Soil & 45.7 & 6.1 & 10.7 & 0.15 & 8.7 & 11.3 & 0.09 & -10.3 & 3.7 \\
\hline Soil amendments & \multicolumn{9}{|c|}{ Post harvest soil properties (after two years of cropping) } \\
\hline T1: F0CI & 48.0 & 6.43 & 9.3 & 0.13 & 10.36 & 10.6 & 0.08 & -21.7 & 3.3 \\
\hline T2: F1CI & 49.6 & 6.58 & 13.6 & 0.18 & 14.67 & 13.5 & 0.10 & -25.3 & 3.9 \\
\hline T3: F2CI & 51.5 & 6.69 & 16.3 & 0.19 & 14.87 & 15.3 & 0.13 & -9.3 & 4.7 \\
\hline T4: F3CI & 53.3 & 6.75 & 17.9 & 0.16 & 14.47 & 16.7 & 0.15 & -7.7 & 5.3 \\
\hline T5: F4CI & 54.0 & 6.93 & 19.6 & 0.15 & 16.63 & 18.3 & 0.15 & -8.3 & 6.7 \\
\hline T6: F0AWDI & 50.7 & 6.50 & 10.9 & 0.11 & 10.70 & 9.7 & 0.09 & -17.6 & 3.6 \\
\hline T7: F1AWDI & 52.6 & 6.59 & 14.1 & 0.17 & 13.72 & 12.9 & 0.12 & -14.3 & 4.0 \\
\hline T8: F2AWDI & 54.7 & 6.71 & 16.7 & 0.20 & 15.97 & 14.6 & 0.14 & -9.3 & 5.9 \\
\hline T9: F3AWDI & 55.3 & 6.83 & 18.5 & 0.19 & 14.97 & 17.7 & 0.15 & -6.5 & 6.8 \\
\hline T10: F4AWDI & 56.0 & 6.91 & 20.6 & 0.17 & 14.73 & 19.5 & 0.16 & -3.6 & 7.9 \\
\hline $\mathrm{LSD}_{0.05}$ & 2.245 & 0.265 & 2.67 & 0.02 & 1.45 & 1.7 & 0.05 & 2.8 & 0.56 \\
\hline $\begin{array}{c}\text { Level of } \\
\text { significance }\end{array}$ & ** & NS & ** & $* *$ & * & * & * & $* * *$ & $* * *$ \\
\hline
\end{tabular}

from the total iron content in soil, where biochar amendment might have contributed as an additional source.

\subsection{Correlation of Cumulative $\mathrm{CH}_{4}$ Emissions with Grain Yield and Soil Properties}

There were negative correlations between total seasonal $\mathrm{CH}_{4}$ fluxes with grain yield, harvest index, soil $\mathrm{pH}$, soil $\mathrm{Eh}$, soil porosity, soil organic carbon, total $\mathrm{N}$, available $\mathrm{P}$ and $\mathrm{SO}_{4}-\mathrm{S}$, free iron oxide contents in soil under both dry and wet seasons (Table 3), while positive correlations were recorded with rice plant productive tillers and aboveground biomass.

\section{Discussion}

In this study, the seasonal $\mathrm{CH}_{4}$ emission trends were found significantly high in dry boro season compared to wet aman season, which may be due to the variation in yield potential of the rice cultivars, irrigation water supply and consumption, meteorological and rice rhizosphere environmental variations within the seasons. $\mathrm{CH}_{4}$ flux was higher during reproductive stage of rice plant in all treatments, which may be due to higher availability of labile organic $\mathrm{C}$ from the decomposition of soil organic materials (Dubey, 2005), higher diffusion rate of $\mathrm{CH}_{4}$ gas through rice root and shoot aerenchyma from rice rhizosphere zone 
Table 3. Pearson's correlation co-efficient of $\mathrm{CH}_{4}$ emissions with selected rice plant growth, yield components and soil properties.

\begin{tabular}{|c|c|c|c|}
\hline & & $\begin{array}{c}\text { Correlation } \\
\text { coefficient (r) } \\
\text { Wet Season }\end{array}$ & $\begin{array}{c}\text { Correlation } \\
\text { coefficient (r) } \\
\text { Dry Season }\end{array}$ \\
\hline \multirow{5}{*}{$\begin{array}{l}\text { Growth and } \\
\text { yield } \\
\text { components }\end{array}$} & Plant height & 0.454 & 0.398 \\
\hline & Productive tillers hill ${ }^{-1}$ & $0.557^{\star}$ & $0.648^{\star}$ \\
\hline & Above ground biomass & $0.679^{* *}$ & $0.648^{*}$ \\
\hline & Grain yield & $-0.487^{\star}$ & $-0.581^{\star}$ \\
\hline & Harvest index & -0.345 & -0.438 \\
\hline \multirow{9}{*}{$\begin{array}{c}\text { Soil } \\
\text { properties }\end{array}$} & Soil porosity & $-0.786^{* * *}$ & $-0.568^{\star}$ \\
\hline & Soil organic carbon & -0.05 & -0.009 \\
\hline & $\mathrm{T}-\mathrm{N}$ & -0.042 & -0.057 \\
\hline & Soil pH & -0.359 & -0.470 \\
\hline & Soil Eh & $-0.788^{* * *}$ & $-0.689^{\star *}$ \\
\hline & Available P & -0.264 & -0.175 \\
\hline & Available S & $-0.589^{\star \star}$ & $-0.668^{\star *}$ \\
\hline & Ex. $\mathrm{K}_{2} \mathrm{O}$ & 0.463 & $0.517^{\star}$ \\
\hline & Free iron oxide & $-0.687^{\star \star}$ & $-0.835^{\star \star \star}$ \\
\hline
\end{tabular}

being supported by Kludge et al. (1993) and Hiya et al. (2020). The sharp fall in $\mathrm{CH}_{4}$ emission rates at grain maturation stage in all the treatment combinations might be due to the aging of rice plant, leaf senescence, lack of available water and labile organic C as supported by Cai et al. (1997).

In this study grain yield was significantly influenced by biochar amendments and irrigation practices. The findings confirmed that biochar amendments 15 $20 \mathrm{t} / \mathrm{ha}$ with NPKS fertilizers (50\% of the recommended doze) maximized rice yield under AWDI method. In the dry boro season, rice yield was increased by $19.6 \%, 13.6 \%$ and $6.5 \%$ with biochar amendments at $15 \mathrm{t} / \mathrm{ha}, 20 \mathrm{t} / \mathrm{ha}$ and $30 \mathrm{t} / \mathrm{ha}$ respectively, under conventional irrigation; whereas the corresponding yield increments were $19.0 \%, 14.2 \%$ and $6.9 \%$ respectively, under AWDI method. The yield increments with biochar amendments following AWDI could be due to the maximum productive tillers/hill and higher nutrients availability to rice grain compared to other treatments. Sanjit et al. (2016) reported that rice grain yield $\left(5950 \mathrm{~kg} \cdot \mathrm{ha}^{-1}\right)$ was a bit higher in conventional irrigation compared to the AWDI treated field plot yield $\left(5820 \mathrm{~kg} \cdot \mathrm{ha}^{-1}\right)$ during the dry boro season in Bangladesh. Ali et al. (2019) also reported that the AWDI treatment showed superiority for the rice yield performance and seasonal $\mathrm{CH}_{4}$ emission reduction, water savings, and maximum water productivity index under the dry seasonal conditions in Bangladesh. It was also reported that moderate wetting and drying increased rice yield, decreased water use and $\mathrm{CH}_{4}$ emissions (Hiya et al. 2020; Yang et al., 2016). In this study, biochar applications 20 - $30 \mathrm{t} / \mathrm{ha}$ under alternate wetting and drying (AWDI) irrigation resulted least cumulative $\mathrm{CH}_{4}$ emissions and GWPs, while highest water productivity and moderate yield performance were found in the rainfed wet season and dry boro season. The lower $\mathrm{CH}_{4}$ emis- 
sion under AWDI treated field plots may be due to increased aeration, stabilization of soil organic carbon, improved soil redox potential status and accumulation of free iron oxides, sulfate ions which acted as electron acceptors, thereby, reduced methanogens' activity. On the contrary, Ali et al. (2015) reported that biochar amendments in paddy soils increased cumulative $\mathrm{CH}_{4}$ emissions. This contrasting result may be due to the variation in the composition of biochar as well as different agro-ecological zones. Zhang et al. (2012) reported that the soil amendment with biochar was found effective for mitigating $\mathrm{CH}_{4}$ emission, which also increased rice yield by $25 \%-26 \%$ compared to inorganic fertilizers. Ali et al. (2013) also reported that intermittent irrigations significantly reduced total seasonal $\mathrm{CH}_{4}$ emissions by $27 \%$ compared to conventional (124 $\mathrm{kg} \mathrm{CH}_{4} / \mathrm{ha}$ ) irrigated rice paddy field. In this study, biochar amendments improved the soil redox status and soil porosity, mostly observed under the AWDI treated field plots. Consequently, total seasonal $\mathrm{CH}_{4}$ emission significantly decreased in AWDI plot compared to the conventional irrigated rice field. Hiya et al. (2020) found that total GWP of $\mathrm{CH}_{4}$ significantly decreased with AWDI treatments as compared to continuous flooded plots. This result also showed that AWD irrigation system is better than conventional irrigation in terms of water productivity index and water savings. Higher productivity index was found in biochar amended field plots under the AWDI method compared to conventional irrigation. Singh et al. (2019) reported that combined application of rice husk biochar and FYM with reduced chemical fertilizer under less water inputs was effective to sustain wheat crop yield in the highly vulnerable dry tropical agro-ecosystem of India. Hossain et al. (2016) reported that water productivity increased from $0.35 \mathrm{~kg} \cdot \mathrm{m}^{-3}$ to 0.65 $\mathrm{kg} \cdot \mathrm{m}^{-3}$ following better research management over the farmers' practice, environment friendly technology for reducing groundwater use in the irrigated ecosystem. Xiao et al. (2018) reported that rice straw biochar amendments at $20 \mathrm{t} / \mathrm{ha}$ and $40 \mathrm{t} /$ ha significantly decreased $\mathrm{CH}_{4}$ emissions by $29.7 \%$ and $15.6 \%$, respectively, while rice yield was increased by $24 \%$ and $33 \%$ and irrigation water productivity was increased by $36 \%$ and $42 \%$, respectively, over the control. In this study, biochar amendments $20-30 \mathrm{t} / \mathrm{ha}$ showed the maximum free iron oxide contents under both AWDI and conventional irrigated (CI) field soils, which was supported by Ali et al. (2014).

This study showed that there were negative correlations between total seasonal $\mathrm{CH}_{4}$ fluxes with grain yield, water productivity index, soil $\mathrm{pH}$, soil Eh, soil porosity, soil organic carbon, total $\mathrm{N}$, available $\mathrm{P}$ and $\mathrm{S}$ (Table 3), while positive correlations were recorded with plant productive tillers and above ground biomass. Hiya et al. (2020) stated that total seasonal $\mathrm{CH}_{4}$ flux was negatively correlated with grain yield, water productivity index, soil Eh, organic matter, total N, available $\mathrm{P}$ and $\mathrm{S}$, soil porosity and soil $\mathrm{pH}$ under continuous irrigated treatment. Denier van Der Gon et al. (2002) reported that rice grain yield was negatively correlated with seasonal $\mathrm{CH}_{4}$ flux. The increased water productivity of rice and water saving aspects will make farmers and other stakeholders to adopt AWDI technique. Therefore, biochar applications@15-20 t/ha with half of the 
recommended chemical fertilizers and adopting alternate wetting drying irrigations may be a feasible technique for reducing yield scaled $\mathrm{CH}_{4}$ emission as well as GWPs and sustaining rice productivity through improving soil properties and rice rhizosphere environmental conditions.

\section{Conclusion}

The findings from the field experiments confirmed that biochar amendments @15 - $20 \mathrm{t} / \mathrm{ha}$ with half of the recommended chemical (NPKS) fertilizers maximized rice yield under AWDI method especially in dry boro season rice cultivation. Higher amendments of biochar @20 - 30 t/ha with alternate wetting and drying (AWDI) irrigation resulted least cumulative $\mathrm{CH}_{4}$ emissions and GWPs, while the highest water productivity and moderate yield performance were found in the rainfed wet season and dry boro season. Therefore, biochar amendments @15 - $20 \mathrm{t} / \mathrm{ha}$ along with half of the recommended inorganic fertilizers under alternate wetting and drying irrigations may be adopted as an integrated package approach to adapt in hot humid and water scarce conditions for reducing yield scaled $\mathrm{CH}_{4}$ emission as well as GWPs, while increasing water productivity and sustaining rice productivity to meet the national food security.

\section{Acknowledgements}

The authors are highly grateful to the Bangladesh Agricultural University Research System (BAURES) as well as Bangladesh Agricultural University, for providing financial support after this research Project (Project No: 2017/243/BAU).

\section{Conflicts of Interest}

There is no conflict of interest regarding publishing the findings of this research.

\section{References}

Ahmad, M. D., Kirby, M., Islam, M. S., Hossain, M. J., \& Islam, M. M. (2014). Groundwater Use for Irrigation and Its Productivity: Status and Opportunities for Crop Intensification for Food Security in Bangladesh. Water Resource Management, 28, 1415-1429. https://doi.org/10.1007/s11269-014-0560-Z

Ahmed, A. U., Ahmad, K., Chou, V., Hernandez, R., Menon, F. N., Naher, F., \& Yu, B. (2013). The Status of Food Security in the Feed the Future Zone and Other Regions of Bangladesh: Results from the 2011-2012 Bangladesh Integrated Household Survey. International Food Policy Research Institute Report.

Ali, M. A. (2008). Effect of Soil Amendments Having Electron Acceptors for Mitigating Methane Emission during Rice (Oryza sativa) Cultivation. Ph.D. Thesis, Division of Applied Life Science, Gyeongsang National University.

Ali, M. A., Hoque, A., \& Kim, P. J. (2013). Mitigating Global Warming Potentials of Methane and Nitrous Oxide Gases from Rice Paddies under Different Irrigation Regimes. AMBIO, 42, 357-368. https://doi.org/10.1007/s13280-012-0349-3

Ali, M. A., Inubushi, K., Kim, P. J., \& Amin, S. (2019) Management of Paddy Soil towards Low Greenhouse Gas Emissions and Sustainable Rice Production in the Changing Climatic Conditions. In M. L. Larramendy, \& S. Soloneski (Eds.), Soil Contamination 
and Alternatives for Sustainable Development (pp. 1-19). Intech Open Publishers.

Ali, M. A., Kim, P. J., \& Inubushi, K. (2015). Mitigating Yield-Scaled Greenhouse Gas Emissions through Combined Application of Soil Amendments: A Comparative Study between Temperate and Subtropical Rice Paddy Soils. Science of the Total Environment, 529, 140-148. https://doi.org/10.1016/j.scitotenv.2015.04.090

Ali, M. A., Sattar, M. A., Islam, M. N., \& Inubushi, K. (2014). Integrated Effects of Organic, Inorganic and Biological Amendments on Methane Emission, Soil Quality and Rice Productivity in Irrigated Paddy Ecosystem of Bangladesh: Field Study of Two Consecutive Rice Growing Seasons. Plant and Soil, 378, 239-252.

https://doi.org/10.1007/s11104-014-2023-y

Allison, L. E. (1965). Organic Carbon. In C. A. Black, D. D. Evans, J. L. White, L. E. Ensminger, F. E. Clark (Eds.), Methods of Soil Analysis, Part 2 (pp. 1367-1376). American Society of Agronomy, Madison.

Bangladesh Bureau of Statistics (BBS) (2015). Statistical Year Book of Bangladesh 2015: Bangladesh Bureau of Statistics.

Bouman, B. A. M., Lampayan, R. M., \& Tuong, T. P. (2007) .Water Management in Irrigated Rice: Coping with Water Scarcity. International Rice Research Institute.

Cai, Z., Xing, G., Yan, X., Xu, H., Tsuruta, H., Yagi, K., \& Minami, K. (1997). Methane and Nitrous Oxide Emissions from Paddy Fields as Affected by Nitrogen Fertilizers and Water Management. Plant and Soil, 196, 7-14.

https://doi.org/10.1023/A:1004263405020

Dubey, S. K. (2005). Microbial Ecology of Methane Emission in Rice Agro-Ecosystem: A Review. Applied Ecology and Environmental Research, 3, 1-27.

Hiya, H. J., Ali, M. A., Baten, M. A., \& Barman, S. C. (2020) Effect of Water Saving Irrigation Management Practices on Rice Productivity and Methane Emission from Paddy Field. Journal of Geoscience and Environment Protection, 8, 182-196. https://doi.org/10.4236/gep.2020.89011

Hossain, M. B., Roy, D., Paul, P. L. C., \& Islam, M. T. (2016). Water Productivity Improvement Using Water Saving Technologies in Boro Rice Cultivation. Bangladesh Rice Journal, 20, 17-22.

IPCC (2007). Climate Change 2007: The Physical Science Basis. Contribution of Working Group I to the Fourth Assessment Report of the Intergovernmental Panel on Climate Change. Cambridge University Press.

Jaafar, M. N., Saad, P., \& VelArjunan, S. N. (2000). A Computational Model for Water Use Efficiency in Rice Production. Teknologi Maklumat, 12, 1-13.

Kludge, H. K., Delaune, R. D., \& Patrick, W. H. (1993). Aerenchyma Formation and Methane and Oxygen Exchange in Rice. Soil Science Society of America Journal, 57, 386-391. https://doi.org/10.2136/sssaj1993.03615995005700020017x

Lehmann, C. J., \& Rondon, M. (2006). Bio-Char Soil Management on Highly-Weathered Soils in the Tropics. In N. T. Uphoff (Ed.), Biological Approaches to Sustainable Soil Systems (pp. 517-530). CRC Press.

Loeppert, R. H., \& Inskeep, W. P. (1996). Iron. In D. L. Sparks, A. L. Page, R. H. Loeppert, C. T. Johnston, M. E. Sumner, \& J. M. Bigham (Eds.), Methods of Soil Analysis: Part 3 Chemical Methods (pp. 639-664). Soil Science Society of America and American Society of Agronomy. https://doi.org/10.2136/sssabookser5.3.c23

Mosier, A. R., Halvorson, A. D., Reule, C. A., \& Liu, X. J. (2006). Net Global Warming Potential and Greenhouse Gas Intensity in Irrigated Cropping Systems in Northeastern Colorado. Journal of Environmental Quality, 35, 1584-1598. 
https://doi.org/10.2134/jeq2005.0232

Nelson, D. W., \& Sommers, L. E. (1980). Total Nitrogen Analysis of Soil and Plant Tissues. Journal of Association of Official Analytical Chemists, 63, 770-778. https://doi.org/10.1093/jaoac/63.4.770

Nieder, R., \& Benbi, D. K. (2008). Bidirectional Biosphere-Atmosphere Interactions. Carbon and Nitrogen in the Terrestrial Environment (pp. 235-305). Springer. https://doi.org/10.1007/978-1-4020-8433-1_8

Olsen, S. R., \& Sommers, L. E. (1982). Phosphorus. In A. L. Page, et al. (Eds.), Methods of Soil Analysis: Part 2. Chemical and Microbiological Properties (2nd ed., pp. 403-430). ASA and SSSA, Madison.

Rolston, D. E. (1986). Gas Flux. In A. Klute (Ed.), Methods of Soil Analysis: Part 1 Physical and Mineralogical Methods, Second Edition (pp. 1103-1119). Soil Science Society of America and American Society of Agronomy. https://doi.org/10.2136/sssabookser5.1.2ed.c47

Sanjit, C. B., Ali, M. A, Hiya, H. J., \& Sattar, M. A. (2016). Effect of Water Management Practices on Rice Yield, Water Productivity and Water Savings under Irrigated Rice Paddy Ecosystem. Journal of Environmental Science and Natural Resources, 9, 79-84.

Singh, R., Kumari, T., Verma, P., Singh, B. P., \& Raghubanshi, A. K. (2021). Compatible Package-Based Agriculture Systems: An Urgent Need for Agro-Ecological Balance and Climate Change Adaptation. Soil Ecology Letters. https://doi.org/10.1007/s42832-021-0087-1

Singh, R., Singh, P., \& Singh, H. (2019). Impact of Sole and Combined Application of Biochar, Organic and Chemical Fertilizers on Wheat Crop Yield and Water Productivity in a Dry Tropical Agro-Ecosystem. Biochar, 1, 229-235.

https://doi.org/10.1007/s42773-019-00013-6

Singh, S., Singh, J. S., \& Kashyap, A. K. (1999). Methane Flux from Irrigated Rice Fields in Relation to Crop Growth and N-Fertilization. Soil Biology and Biochemistry, 31, 12191228. https://doi.org/10.1016/S0038-0717(99)00027-9

Tuong, T. P. (2003). Strategies for Increasing Water Productivity in Rice Irrigation Systems: Water-Saving Irrigation Technologies. Proceedings of the International Conference on Increasing Water-Use Efficiency in Lowland Rice Cultivation (pp. 39-65). Rural Development Administration, Republic of Korea.

van der Gon, H. A. C. D., Kropff, M. J., van Breemen, N., Wassmann, R., Lantin, R., S., Aduna, E., \& Corton, T. M. (2002). Optimizing Grain Yields Reduces $\mathrm{CH}_{4}$ Emissions from Rice Paddy Fields. Proceedings of the National Academy of Sciences of the United States of America, 99, 12021-12024. https://doi.org/10.1073/pnas.192276599

Xiao, Y. N., Yang, S. H., Xu, J. Z., Ding, J., Sun, X., \& Jiang, Z. W. (2018). Effect of Biochar Amendment on Methane Emissions from Paddy Field under Water-Saving Irrigation. Sustainability, 10, Article No. 1371. https://doi.org/10.3390/su10051371

Yang, J. C., Zhou, Q., \& Zhang, J. H. (2016). Moderate Wetting and Drying Increases Rice Yield and Reduces Water Use, Grain Arsenic Level and Methane Emission. The Crop Journal, 5, 151-158. https://doi.org/10.1016/j.cj.2016.06.002

Zhang, A. F., Bian, R. J., Pan, G. X., Cui, L. Q., Hussain, Q., Li, L. Q., Zheng, J. W., Zhang, X. H., Han, X. J., \& Yu, X. Y. (2012). Effects of Biochar Amendment on Soil Quality, Crop Yield and Greenhouse Gas Emission in a Chinese Rice Paddy: A Field Study of Two Consecutive Rice Growing Cycles. Field Crops Research, 127, 153-160. https://doi.org/10.1016/j.fcr.2011.11.020 